\title{
The therapeutic effect of anti-CD52 treatment in murine experimental autoimmune encephalomyelitis is associated with altered IL-33 and ST2 expression levels
}

Mark Barbour, Rachel Wood, Shehla U Hridi, Chelsey Wilson, Grant McKay, Trevor J Bushell, Hui-Rong Jiang

Strathclyde Institute of Pharmacy and Biomedical Sciences, University of Strathclyde, 161 Cathedral Street, Glasgow, G4 0RE, UK

Correspondence to: H-R Jiang, Strathclyde Institute of Pharmacy and Biomedical Sciences, University of Strathclyde, Glasgow, G4 0RE, UK. Tel: +44 1415482620. Email: huirong.jiang@strath.ac.uk

\footnotetext{
Abbreviations

ADCC, antibody-dependent cellular cytotoxicity; APC, antigen presenting cell; CDC, complement-dependent cytolysis; CFA, complete freunds adjuvant; CNS, central nervous system; DC, dendritic cell; EAE, experimental autoimmune encephalomyelitis; GFAP, glial fibrillary acidic protein; IL, interleukin; MOG, myelin oligodendrocyte glycoprotein; MS, multiple sclerosis; NK cell, natural killer cell; PTX, pertussis toxin; RRMS, relapsingremitting MS; SLE, systemic lupus erythematosus; sST2, soluble ST2; ST2L, ST2 ligand.
} 


\section{$\underline{\text { Abstract }}$}

Experimental autoimmune encephalomyelitis (EAE) mice were administered with murine anti-CD52 antibody to investigate its therapeutic effect and whether the treatment modulates IL-33 and ST2 expression. EAE severity and central nervous system (CNS) inflammation were reduced following the treatment, which was accompanied by peripheral $\mathrm{T}$ and $\mathrm{B}$ lymphocyte depletion and reduced production of various cytokines including IL-33, while sST2 was increased. In spinal cords of EAE mice, while the number of IL- $33^{+}$cells remained unchanged, the extracellular level of IL-33 protein was significantly reduced in anti-CD52 antibody treated mice compared with controls. Furthermore the number of $\mathrm{ST}^{+}$cells in the spinal cord of treated EAE mice was downregulated due to decreased inflammation and immune cell infiltration in the CNS. These results suggest that treatment with anti-CD52 antibody differentially alters expression of IL-33 and ST2, both systemically and within the CNS, which may indicate IL-33/ST2 axis is involved in the action of the antibody in inhibiting EAE.

\section{Key Words}

Multiple sclerosis, experimental autoimmune encephalomyelitis, CD52, IL-33, ST2 


\section{Introduction}

Multiple sclerosis (MS) is an autoimmune inflammatory disease of the central nervous system (CNS) and one of the leading causes of neurological disability in young adults, affecting around 2.5 million people worldwide (Pugliatti et al., 2002). While prevalence rates vary, particularly high levels are observed in North America (around 100 per 100,000 population) and the UK (200 per 100,000) (Mackenzie et al., 2014). A recent study suggested annual costs to the UK of approximately £2.3 billion (Fineberg et al., 2013). At present there is no cure with current treatments limited to management of symptoms and relapses, therefore further research is crucial to develop novel therapies.

While the precise aetiology is not yet fully understood, MS is thought to be initiated by autoreactive $\mathrm{T}$ lymphocytes infiltrating the CNS where they are activated by myelin and axonal antigens via antigen presenting cells (APCs) (Compston and Coles, 2008; Weiner, 2008). This is followed by secretion of proinflammatory and cytotoxic mediators which leads to recruitment and activation of other immune cells including B cells, dendritic cells (DCs) and macrophages as well as activation of CNS resident cells (e.g. astrocytes and microglia). The ensuing inflammatory response results in demyelination, axonal loss, lesion development and subsequent neurological disability (Compston and Coles, 2008; Weiner, 2008).

Alemtuzumab is a monoclonal antibody that binds to CD52, a glycosylated cell-surface protein that is highly expressed on $\mathrm{T}$ and B lymphocytes but is also found at lower levels on other immune cells such as natural killer (NK) cells, monocytes, macrophages and DCs (Rao et al., 2012). It was originally used in the treatment of some types of cancer including chronic lymphocytic leukaemia and cutaneous T-cell lymphoma (Cox et al., 2005; Zhang et al., 2013). Its therapeutic action is proposed to be via the depletion of $\mathrm{T}$ and $\mathrm{B}$ lymphocytes followed by a gradual repopulation but with an altered repertoire consisting of increased 
regulatory $\mathrm{T}$ cells (Tregs) relative to other $\mathrm{CD}^{+} \mathrm{T}$ cells and a shift in cytokine production towards a more anti-inflammatory profile (Cox et al., 2005; Pant et al., 2016; Thompson et al., 2010). Due to the key roles for both $\mathrm{T}$ and B lymphocytes in MS pathogenesis, alemtuzumab underwent successful clinical trials and was subsequently approved for use in MS. It has been shown to reduce relapse rate and sustained accumulation of disability in patients with RRMS (Cohen et al., 2012; Coles et al., 2012). However the exact mechanism of action beyond lymphocyte depletion is not yet fully understood, and further studies are also essential to understand the associated side effects such as infusion-associated reactions and autoimmune adverse events or possible development of certain malignancies (Guarnera et al., 2017; Havrdova et al., 2017).

IL-33 is a member of the IL-1 cytokine family (Baekkevold et al., 2003; Schmitz et al., 2005) and the functional ligand of the ST2 receptor. The membrane-bound form of ST2 is expressed on T cells (Lohning et al., 1998; Schiering et al., 2014; Xu et al., 1998; Yang et al., 2011), mast cells (Moritz et al., 1998), NK cells, basophils (Smithgall et al., 2008) and group 2 innate lymphoid cells (Neill et al., 2010; Price et al., 2010). A soluble isoform of ST2 (sST2) also exists which acts as a decoy receptor of IL-33 (Hayakawa et al., 2007) and is considered a potential biomarker in cardiovascular diseases (Dieplinger and Mueller, 2015; Miller et al., 2008; Sanada et al., 2007). The IL-33/ST2 axis plays an important role in various conditions such as mediating type 2 immune responses in parasite infection (Hung et al., 2013; Moro et al., 2010; Yasuda et al., 2012) and allergic inflammation (Bartemes et al., 2012; Louten et al., 2011; Oboki et al., 2010). IL-33 is also shown to enhance CD8 ${ }^{+} \mathrm{T}$ cell and innate lymphoid cell responses to viral infection (Bonilla et al., 2012; Monticelli et al., 2011), while increased IL-33 levels are associated with bone erosion in patients with rheumatoid arthritis (Xiangyang et al., 2012) and IL-33 exacerbates joint inflammation in collagen induced arthritis model (Xu et al., 2008). Interestingly, the highest expression levels 
of mouse IL-33 mRNA are observed in the brain and spinal cord among all the tissues tested (Schmitz et al., 2005), suggesting IL-33 may have important functionality within the CNS. In support of this, genetic variants of IL-33 are associated with increased susceptibility to Alzheimer's disease (AD) (Chapuis et al., 2009) whilst IL-33 administration has been shown to reverse synaptic plasticity and cognitive deficits in a mouse model of AD (Fu et al., 2016). In addition, IL-33 promotes recovery after CNS injury in mice (Gadani et al., 2015) and ST2 deficient mice display increased susceptibility to viral-induced encephalitis (Franca et al., 2016). In MS, IL-33 levels are upregulated both within the CNS and peripheral tissues (Christophi et al., 2012). We have previously shown that IL-33 plays a therapeutic role in EAE by switching pathogenic Th1/Th17 responses towards a Th2 phenotype (Jiang et al., 2012) with increased EAE severity in ST2 deficient mice (Jiang et al., 2012; Milovanovic et al., 2012). This confirms IL-33 as a key mediator of immune responses in various CNS disorders including MS.

In this study we aimed firstly to investigate the therapeutic effect of anti-CD52 treatment by utilising a mouse model of MS, and to further characterise the mechanisms of action of antiCD52 antibody and whether IL-33 and ST2 are involved in its function in EAE. 


\section{Materials and Methods}

\subsection{Mice}

Naïve C57BL/6 mice were bred and maintained in the Biological Procedure Unit at the University of Strathclyde. Female animals at 9-10 weeks of age were used in all experiments. All animal experiments were performed under the guidelines of the UK Animals (Scientific Procedures) Act 1986 and were conducted under a Project License granted by the UK Home Office and with local ethical approval.

\subsection{EAE induction and assessment}

Mice were immunized s.c. on day 0 with $100 \mu \mathrm{l}$ of $150 \mu$ MOG $_{35-55}$ (ChinaPeptides Co Ltd) emulsified in complete Freunds adjuvant (CFA; Sigma) supplemented with $400 \mu \mathrm{g}$ Mycobacterium tuberculosis (BD Biosciences). In addition, each mouse received $150 \mathrm{ng}$ pertussis toxin (PTX; Tocris Bioscience) in $100 \mu$ PBS injected i.p. on day 0 and again on day 2. Mice were monitored daily for signs of disease development and given a clinical score based on the following evaluation system: $0=$ no clinical sign; $0.5=$ partial loss of tail tone; $1.0=$ complete loss of tail tone; $1.5=$ altered gait; $2.0=$ hind limb weakness; $2.5=$ paralysis of one leg; 3.0=hind limb paralysis; 3.5=hind limb paralysis with significantly reduced mobility; 4.0 =forelimb involvement; 5.0=moribund. There was no unexpected mortality in our studies.

\subsection{Anti-mouse CD52 monoclonal antibody treatment}

Anti-mouse CD52 monoclonal antibodies were generated and provided by Genzyme as previously described (Turner et al., 2015). Following onset of clinical signs of disease, mice were treated with $100 \mu \mathrm{l}$ of either vehicle (phosphate buffered saline; PBS) or $10 \mathrm{mg} / \mathrm{kg}$ murine anti-CD52 injected s.c. into the neck scruff once a day for five consecutive days (day 13 to day 17). 


\subsection{Spinal cord collection and histology}

Mice were sacrificed at the specified time points and, following PBS perfusion, intact spinal cords were flushed out with PBS by hydrostatic pressure using a sterile 19G needle. Frozen spinal cord tissue sections were then stained with standard haematoxylin and eosin (H\&E) staining or with antibodies against CD45 (\#14-0451-85), CD4 (\#14-0042-85), F4/80 (\#144801-85; all eBioscience), IL-33 (R\&D systems \#MAB3626) or ST2 (Sigma \#PRS3363) followed by incubation with an appropriate biotin-conjugated secondary antibody (eBioscience, UK), horseradish peroxidase and ImmPACT AMEC red peroxidase substrate (Vector Lab, UK) for detection. Isotypes with matching IgG were used as negative controls for all antibody staining. For immunofluorescence, frozen spinal cord sections were stained with antibodies against ST2, CD45, GFAP (Cell signalling \#3670S) and O1 (eBioscience \#14-6506-82) followed by incubation with appropriate Alexa Fluor-conjugated secondary antibodies (ThermoFisher). Slides were then visualized on a Nikon Eclipse E600 epiflorescent microscope. Quantification of positive staining was carried out using ImageJ, fixed size square frames were evenly distributed across both white and grey matter using a naïve mouse section initially to avoid bias of lesion sites, with nine frames of consistent size and location superimposed over each spinal cord section. The number of either single or double-positive stained cells and the total number of cells were then counted within each frame and the combined total number within each tissue section was presented in each figure.

\subsection{Sample preparation for ELISA}

Mice were sacrificed at various time points and spleens, blood and CNS tissues harvested. For splenocyte ELISA, single cell suspensions were cultured in 24-well plates at $4 \times 10^{6}$ cells/2ml per well and stimulated with or without $40 \mu \mathrm{g} / \mathrm{ml} \mathrm{MOG}_{35-55}$. Supernatants were collected after 72 hours and cytokine levels determined by ELISA. For serum ELISA, serum 
was isolated from whole blood samples and cytokine levels determined by ELISA. Within serum and spleen samples, the following cytokines were analysed: IL-4, IL-6, IL-10, IL-17, IL-22, IL-33, IFN- $\gamma$, and ST2 (all eBioscience).

For spinal cord and brain homogenate ELISAs, tissues were collected and homogenised in PBS containing protease and phosphatase inhibitor cocktails (ThermoFisher) and centrifuged at $2000 \mathrm{rpm}$ for 5 minutes. The supernatants were then transferred to new tubes and centrifuged at 12,000 rpm for 15 minutes. The supernatants were finally collected for analysis of IL-33 and sST2 levels by ELISA.

\subsection{Flow Cytometry}

Cells from spleen and blood tissues were added to FACS tubes $\left(0.5 \times 10^{6}\right.$ cells per tube). To block non-specific Fc receptors, cells were resuspended in anti-mouse CD16/CD32 Fc block (eBioscience) for 10 minutes before incubation with the appropriate antibodies against: B220 (\#11-0452-82), CD4 (\#53-0041-80), CD8 (\#45-0081-82), CD11b (\#12-0112-82), CD11c (\#53-0114-82), CD19 (\#17-0193-82) and CD49b (\# 17-5971-81; all eBioscience). Cells were then resuspended in $0.5 \mathrm{ml}$ FACS buffer and analysed using a BD FACSCanto system and BD FACSDiva software (both BD Biosciences).

\subsection{Statistics}

All data are shown as mean \pm SEM. Statistical analysis of EAE clinical score data was performed using 2-way ANOVA with repeated measures and Bonferroni post hoc tests where appropriate. Other data presented in the study were analysed by two-tailed, unpaired student's t test or one-way ANOVA as appropriate. A $P$ value of less than 0.05 was considered statistically significant. 


\section{$\underline{\text { 3. Results }}$}

\subsection{Anti-CD52 treatment reduces EAE severity and CNS inflammation}

We initially sought to determine the therapeutic effect of anti-CD52 treatment in our mouse model of MS. C57BL/6 mice were immunised with $\mathrm{MOG}_{35-55}$ peptide to induce EAE and, upon onset of observable clinical signs of disease, mice were treated with either a vehicle control (PBS) or $10 \mathrm{mg} / \mathrm{kg}$ murine anti-CD52 once a day for five consecutive days from day 13 to day 17 (Fig 1A). Our data show that treatment with anti-CD52 almost immediately halted disease progression, with EAE severity decreasing after only two injections from $1.3 \pm 0.1$ to $1.0 \pm 0.1$. In comparison, disease severity in control mice continued to increase from $1.3 \pm 0.2$ to $2.5 \pm 0.2$ after two vehicle injections, reaching a peak of $2.6 \pm 0.2$ at day 16 before slowly decreasing to $1.0 \pm 0.2$ at the experiment end-point, day 28 . In contrast, the average score of anti-CD52 treated mice at day 16 was $0.8 \pm 0.1$ and continued dropping to $0.3 \pm 0.1$ by day 28 ( $\mathrm{p}<0.001$ day 15-22; $\mathrm{p}<0.01$ day 23, 24; $\mathrm{p}<0.05$ day 25, 26).

To investigate the extent of inflammation and cellular infiltration in the CNS of these mice, spinal cord tissues were harvested at day 18 after immunisation, one day after the last injection of anti-CD52 or vehicle, and H\&E staining was carried out. Histological examination showed a reduction in the number of lesions and infiltrating cells particularly in the white matter of anti-CD52 spinal cord sections compared to vehicle control tissues (Fig 1B). The reduced infiltration of immune cells was quantified using an antibody against CD45

(Fig 1B, C), which clearly confirmed that there is a significant reduction in CD $45^{+}$cells in the spinal cords of mice receiving anti-CD52 $(61 \pm 6$ cells, $\mathrm{p}<0.001)$ relative to the vehicle control group (416 \pm 19 cells). Further analysis in separate spinal cord sections revealed that the majority of these infiltrating cells were $\mathrm{CD} 4^{+} \mathrm{T}$ cells and $\mathrm{F} 4 / 80^{+}$macrophages. The number 
of $\mathrm{CD}^{+} \mathrm{T}$ cells was reduced from $125 \pm 16$ in vehicle controls to just $8 \pm 2$ in following antiCD52 treatment $(\mathrm{p}<0.001)$ while $\mathrm{F} 4 / 80^{+}$cells decreased from $274 \pm 10$ to $37 \pm 7(\mathrm{p}<0.001)$.

Similarly, immune cell infiltration was also decreased in the brain tissues of anti-CD52 treated mice, with the number of $\mathrm{CD}_{4} 5^{+}$cells decreasing to $179 \pm 10$ from $225 \pm 10$ in vehicle control brains $(\mathrm{p}<0.05$; data not shown).

\subsection{Anti-CD52 treatment results in systemic $T$ and $B$ lymphocyte depletion}

Treatment with anti-CD52 has been shown to reduce circulating T and B lymphocytes in MS patients. Here we analysed the effect of anti-CD52 treatment on the level of CD4 ${ }^{+}$and CD8 ${ }^{+}$ $\mathrm{T}$ cells as well as B cells $\left(\mathrm{CD} 19^{+} \mathrm{B} 220^{+}\right)$in both the spleen and blood of EAE mice. Tissues were collected either one day (day 18 post immunisation) or 11 days (day 28) after the final injection of anti-CD52 or vehicle. At day 18, treatment with anti-CD52 resulted in a substantial decrease in the total number of circulating $\operatorname{CD}^{+}\left(0.06 \pm 0.01 \times 10^{6}, \mathrm{p}<0.001\right)$ and CD8 $^{+} \mathrm{T}$ cells $\left(0.03 \pm 0.01 \times 10^{6}, \mathrm{p}<0.001\right)$ compared to vehicle controls $\left(1.1 \pm 0.1 \times 10^{6}\right.$ and $0.73 \pm 0.08 \times 10^{6}$ respectively; Fig 2 A). Similar results were also seen in spleen samples (Fig 2B) with $\mathrm{CD}^{+} \mathrm{T}$ cells decreasing from $6.7 \pm 0.3 \times 10^{6}$ to $0.5 \pm 0.1 \times 10^{6}(\mathrm{p}<0.001)$ and $\mathrm{CD}^{+} \mathrm{T}$ cells from $4.7 \pm 0.2 \times 10^{6}$ to $0.3 \pm 0.06 \times 10^{6}(\mathrm{p}<0.001)$. In addition, total CD19 ${ }^{+} \mathrm{B} 220^{+} \mathrm{B}$ cell numbers were also reduced in the blood $\left(0.3 \pm 0.1 \times 10^{6}, \mathrm{p}<0.001\right.$; Fig $\left.2 \mathrm{~A}\right)$ and spleen $(4.7 \pm 0.7$ $\mathrm{x} 10^{6}, \mathrm{p}<0.001$; Fig 2B) following administration of anti-CD52 relative to the vehicle group (2.8 $\pm 0.3 \times 10^{6}$ and $21.5 \pm 1.4 \times 10^{6}$ respectively).

Depletion of these cells was maintained at day 28. At this time point, the total number of $\mathrm{CD}^{+} \mathrm{T}$ cells was decreased from $1.1 \pm 0.1 \times 10^{6}$ to $0.03 \pm 0.01 \times 10^{6}(\mathrm{p}<0.001)$ in blood and from $9.4 \pm 0.9 \times 10^{6}$ to $0.4 \pm 0.08 \times 10^{6}(\mathrm{p}<0.001)$ in spleen. $\mathrm{CD}^{+}$cells decreased from $0.9 \pm 0.07$ $\mathrm{x} 10^{6}$ to $0.01 \pm 0.003 \times 10^{6}(\mathrm{p}<0.001)$ in blood and from $6.4 \pm 0.5 \times 10^{6}$ to $0.3 \pm 0.05 \times 10^{6}$ 
$(\mathrm{p}<0.001)$ in spleen samples while $\mathrm{CD} 19^{+} \mathrm{B} 220^{+} \mathrm{B}$ cell populations were reduced from $4.9 \pm 0.4 \times 10^{6}$ and $25.2 \pm 1.0 \times 10^{6}$ to $0.4 \pm 0.08 \times 10^{6}(\mathrm{p}<0.001)$ and $5.4 \pm 0.9 \times 10^{6}(\mathrm{p}<0.001)$ in blood and spleen respectively.

\subsection{Anti-CD52 treatment depletes circulating NK cells, but not macrophages or DCs}

In addition to $\mathrm{T}$ and $\mathrm{B}$ lymphocytes, which are known to express CD52 at high levels, we also analysed other immune cells which express CD52 at low levels to determine the effect anti-CD52 treatment has on these cells in the periphery of EAE mice. We found that the number of circulating $\left(0.9 \pm 0.1 \times 10^{6}, \mathrm{p}<0.01\right.$; Fig 3A), but not splenic (Fig 3B), CD49b ${ }^{+} \mathrm{NK}$

cells was decreased in treated mice at day 18 down from $2.2 \pm 0.3 \times 10^{6}$ in vehicle control samples. However, in contrast to consistent depletion of T and B cells, the decrease of NK cell populations was not maintained and at day 28 as the cell numbers were comparable between anti-CD52 treated mice and vehicle controls. Our data also show that the overall cell number of circulating or splenic macrophages and DCs remained unchanged statistically between anti-CD52 treated mice and vehicle controls at either day 18 or day 28.

\subsection{Reduced systemic cytokine levels in EAE mice following anti-CD52 treatment}

To understand the functional impact of lymphocyte depletion, we next investigated both circulating serum cytokine levels (Fig 4A) and the antigen-specific cytokine production profile of splenocytes stimulated with $\mathrm{MOG}_{35-55}$ peptide in vitro (Fig 4B). Our data show that there was no difference in serum levels of IFN- $\gamma$ or IL-6 between anti-CD52 and vehicle treated mice, while IL-4, IL-10, IL-17 and IL-22 were below detection limits. We also determined if there were any changes in IL-33 levels in EAE mice following administration 
of anti-CD52 as IL-33 has recently been highlighted as an important mediator of the immune response and CNS inflammation in MS and EAE. Our data show circulating IL-33 levels were decreased from $63 \pm 26 \mathrm{pg} / \mathrm{ml}$ in control mice to below detectable limits following the final dose of anti-CD52 at day 18 after immunisation (Fig 4A), while the decoy receptor for IL-33, sST2, remained unchanged.

In contrast to serum levels, $\mathrm{MOG}_{35-55}$-induced production of key cytokines involved in EAE was significantly decreased in spleens of treated mice compared to vehicle controls. This included the Th1 cytokine IFN- $\gamma$, the Th17 cytokines IL-17 and IL-22, the Th2 cytokine IL-4 as well as cytokines involved in different aspects of the inflammatory response, IL-6 and IL10. We additionally observed reduced IL-33 secretion by anti-CD52 treated mice splenocytes at day 28 post EAE induction, with levels below the limit of detection compared to that of controls (276 \pm 99 pg/ml; Fig 4B). In contrast, sST2 secretion by MOG peptide re-challenged splenocytes from anti-CD52 treated mice was increased at both day $18(913 \pm 67 \mathrm{pg} / \mathrm{ml}$, $\mathrm{p}<0.001)$ and day $28(206 \pm 37 \mathrm{pg} / \mathrm{ml}, \mathrm{p}<0.001)$ compared to vehicle control equivalents (245 \pm 50 and $9 \pm 5 \mathrm{pg} / \mathrm{ml}$ respectively; Fig 4B).

\subsection{Altered levels of IL-33 and ST2 in the CNS after anti-CD52 treatment}

As IL-33 plays important roles within the CNS under normal and disease conditions in addition to its key immunomodulatory functions, we next determined the levels of IL-33 and sST2 in spinal cord homogenates of vehicle and anti-CD52 treated EAE mice. Similar to the systemic reduction of IL-33 levels in the serum, we observed a decrease in extracellular IL33 in the spinal cord homogenate of anti-CD52 treated mice one day after the final injection, day 18 , from $414 \pm 50 \mathrm{pg} / \mathrm{ml}$ in vehicle controls to $179 \pm 31 \mathrm{pg} / \mathrm{ml}(\mathrm{p}<0.001)$ (Fig $5 \mathrm{~A})$. This was also true in brain homogenate at day 18 (data not shown; vehicle 226 $\pm 27 \mathrm{pg} / \mathrm{ml}$, anti-CD52 
$159 \pm 13 \mathrm{pg} / \mathrm{ml} ; \mathrm{p}<0.05)$. However no difference was observed in sST2 levels within spinal cord homogenates between the groups at any time point (Fig 5A).

To determine the potential cells responsible for the reduction of IL-33 protein levels in the CNS, we next studied the in situ expression of the molecules using immunohistochemical staining. Spinal cord tissues of EAE mice from treated and control groups were collected at day 18 and day 28 after immunisation and analysed. Surprisingly we observed comparable distribution pattern and number of $\mathrm{IL}^{-33^{+}}$cells between treated and untreated mice at both time points (Fig 5B, C). In contrast, the expression of ST2 was shown to be enhanced in the lesions of spinal cord tissues (Fig 5B) and the number of cells expressing ST2 was decreased as a result of anti-CD52 treatment $(288 \pm 12$ cells, $\mathrm{p}<0.05)$ compared to vehicle controls (362 20 cells) at day 18 whereas there was no longer any difference by day 28 (Fig 5B, C). Taken together these results suggest anti-CD52 treatment affects IL-33 and ST2 levels within the CNS during EAE progression.

\subsection{Reduced CNS inflammation accounts for decreased ST2 expression in the spinal cord of anti-CD52 treated mice}

To further determine the phenotype of cells with reduced expression of ST2, we next performed dual fluorescence staining to determine the $\mathrm{ST}^{+}$cells in the spinal cord. We found that the number of $\mathrm{GFAP}^{+}$astrocytes (Fig 6A, D; $\mathrm{p}<0.05$ ) and $\mathrm{O}^{+}$oligodendrocyte progenitor cells (Fig 6B, D; $\mathrm{p}<0.001$ ) was decreased in EAE spinal cords following antiCD52 treatment (45 \pm 8 GFAP, $10 \pm 1$ O1) compared to vehicle controls (74 \pm 5 GFAP, $41 \pm 5$ O1) while we also confirmed a dramatic reduction in $\mathrm{CD} 5^{+}$immune cells (Fig 6C, D; $\mathrm{p}<0.001$ ) as shown in Figure 1. The staining also revealed that ST2 is highly expressed on $\mathrm{GFAP}^{+}$astrocytes (Fig 6A), with lower level co-localisation on $\mathrm{O}^{+}$(Fig 6B) and $\mathrm{CD}^{+} 5^{+}$cells 
(Fig 6C). The number of $\mathrm{ST}^{+}$astrocytes in common lesion areas of the white matter was reduced from $41 \pm 3$ cells in control mice to $26 \pm 5$ cells following anti-CD52 treatment $\left(\mathrm{p}<0.05\right.$, Fig 6E). Furthermore there was also a reduction in $\mathrm{ST}^{+}$oligodendrocyte progenitors ( $2 \pm 1$ cells, $\mathrm{p}<0.05$, Fig $6 \mathrm{E}$ ) and $\mathrm{ST}^{+}{ }^{+}$infiltrating immune cells ( $5 \pm 1$ cells, $\mathrm{p}<0.05$, Fig 6E) compared to vehicle controls ( $11 \pm 3$ and $9 \pm 2$ cells respectively). 


\section{Discussion}

Treatment of relapsing-remitting MS (RRMS) patients with anti-CD52 antibody (Alemtuzumab/Lemtrada) has proven to be effective, with reductions in relapse rate and sustained accumulation of disability (Cohen et al., 2012; Coles et al., 2012) although with risks of adverse events. Here we used a recently developed mouse monoclonal antibody against CD52 in a murine EAE model and confirmed that it replicates the effects in reducing CNS inflammation seen in MS patients. This allows for analysis that would otherwise not be possible in human studies due to inaccessibility to key tissues.

We chose to employ a similar treatment regime as that used with MS patients of five single anti-CD52 injections over five consecutive days following onset of symptoms. After just two anti-CD52 injections, clinical progression began to reverse, with overall severity dramatically reduced in our acute monophasic EAE model as determined by clinical severity scoring and histological analysis of spinal cord tissue, which showed reductions in immune cell infiltration and lesion development. Our data support several recent reports that this antibody reduces clinical scores and disease progression in various murine EAE models (Pant et al., 2016; Turner et al., 2015; von Kutzleben et al., 2016). Taken together, murine anti-CD52 is clearly a potent inhibitor of EAE independent of the model used, indicating its various potential working mechanisms in different MS patients.

It is well documented that alemtuzumab exerts its therapeutic effect in MS by depletion of circulating $\mathrm{T}$ and $\mathrm{B}$ lymphocytes. This is achieved via antibody-dependent cellular cytotoxicity (ADCC) and complement-dependent cytolysis (CDC) due to these cells expressing high levels of CD52 (Rao et al., 2012). CD52 expression levels on mouse immune cells are similar to human CD52 with the exception of a slightly higher expression on mouse neutrophils (Turner et al., 2015). Our results show substantial depletion of both circulating 
and splenic CD4 ${ }^{+} \mathrm{T}$ cells, $\mathrm{CD} 8^{+} \mathrm{T}$ cells and B cells. This was observed one day after the final dose as well as 10 days later which is in agreement with previous studies (Turner et al., 2015; von Kutzleben et al., 2016) confirming the effectiveness of this antibody in lymphocyte depletion. Interestingly, while the total number of $\mathrm{CD}^{+}$and $\mathrm{CD}^{+} \mathrm{T}$ cells decreased by at least 93\% in both blood and spleen in our study, B cell depletion in the spleen was less pronounced (78\%) compared to blood (98\%), which perhaps suggests less effective labelling or ADCC/CDC of B lymphocytes in secondary lymphoid organs. This also agrees with results shown previously in $\mathrm{ABH}$ mice (von Kutzleben et al., 2016), suggesting a common effect across different strains of mice. Not surprisingly, we also observed that $\mathrm{CD}^{+} \mathrm{T}$ cell infiltration into the CNS is decreased which is likely due to the profound systemic depletion of circulating T lymphocytes.

In addition to $\mathrm{T}$ and $\mathrm{B}$ lymphocytes, the number of circulating $\mathrm{CD}_{49 \mathrm{~b}^{+}} \mathrm{NK}$ cells was decreased following the final dose of anti-CD52 suggesting these cells are also targeted for depletion. However this was to a lesser extent than $\mathrm{T}$ and $\mathrm{B}$ lymphocytes, probably due to the lower expression of CD52 on the surface of NK cells compared to these lymphocytes (Turner et al., 2015). Our data nevertheless support the capacity for this drug to target NK cells with decreased NK cell numbers in spleens of naïve mice following treatment with anti-CD52 (Hotta et al., 2016; Turner et al., 2015).

In contrast, our data show that DCs and monocytes/macrophages are not depleted at one or eleven days after anti-CD52 treatment, likely due to the lower expression levels of CD52 on the majority of these cells (Rao et al., 2012). Indeed, alemtuzumab has been shown to have minimal cytolytic effects on isolated myeloid cells in vitro (Rao et al., 2012). However decreased numbers of circulating DCs have been observed 6 months after initiation of treatment of alemtuzumab in RRMS patients (Gross et al., 2016). The discrepancy may be 
due to differential expression of CD52 between distinct DC subsets as has been shown in human blood samples (Rao et al., 2012).

Anti-CD52 antibody treatment in MS and EAE is shown to affect multiple immune and neural pathways involved in disease pathogenesis. The rapid depletion of lymphocytes following anti-CD52 treatment leads to subsequent repopulation of a rebalanced immune system in the EAE mice. Our data of the reduction in antigen specific cytokine production by spleen cells following CD52 administration agree with a previous report that the overall systemic production of both pro- and anti-inflammatory cytokines is reduced in EAE mice shortly after treatment (Turner et al., 2015). While it is likely that CD52-Ab modulates the antigen specific production of $\mathrm{T}$ cell related cytokines such as IL-17, IFN- $\gamma$ and IL-4 via lymphocyte depletion, the modulatory mechanisms for IL-33 might be different as only a small level of IL-33 production has been observed from B cells (Hardman et al., 2013), with no evidence of IL-33 production by T cells. Reduction of IL-33 levels in serum samples of EAE mice one day after the final CD52 antibody treatment correlates with reduced clinical EAE scores and this agrees with findings of increased IL-33 levels in the blood samples of MS patients (Christophi et al., 2012). Interestingly, in contrast, higher levels of sST2 were produced by $\mathrm{MOG}_{35-55}$ stimulated splenocytes of anti-CD52 treated mice. As sST2 binds to extracellular IL-33 and acts as a decoy receptor, increased sST2 levels may be the reason for reduced IL-33 if it is sequestering the cytokine to prevent its function.

Associated with the reduced clinical symptoms and neuroinflammation, our data show that IL-33 levels were reduced in homogenised spinal cord and brain tissues of EAE mice at day 18. The findings agree with a previous report that extracellular levels of IL-33 in the CNS correlate with EAE severity (Chen et al., 2015). Furthermore, elevated IL-33 levels have been detected in normal-appearing white matter and plaque areas of MS patients (Allan et al., 2016; Christophi et al., 2012; Zhang et al., 2014). However, immunohistochemical staining 
revealed no change in the number of IL- $33^{+}$cells within EAE spinal cords between control and treated groups. This suggests anti-CD52 may not alter the number of cells that express IL-33 within the CNS, but rather the amount of IL-33 they produce and release in response to different levels of neuroinflammation.

In contrast, while there was no change of sST2 levels in homogenised CNS tissues between treated and control groups, the number of ST2-expressing cells within white matter regions of EAE spinal cords at peak severity showed a significant reduction following anti-CD52 treatment. After careful examination of the cell numbers in different regions of spinal cord, we found that the decrease in total number of $\mathrm{ST}^{+}$cells in anti-CD52 treated spinal cords was localised to white matter regions where most lesions develop during EAE pathogenesis.

To understand whether the reduction of $\mathrm{ST}^{+}$cells was due to the decreased infiltrating immune cells or reduced expression in CNS resident cells, co-localisation staining was performed with CD45, an immune cell marker, GFAP, an astrocytic marker and O1, a latestage oligodendrocyte progenitor marker. These cell types are known to be present at high levels in EAE inflammatory lesions that predominantly occur in the white matter. Indeed ST2 expression was shown to be reduced in astrocytes, oligodendrocytes and some immune cells, indicating the potential pleiotropic role of IL-33 in CNS inflammation through both immune and CNS resident cells. While IL-33 expression by $\mathrm{CD}^{+} 5^{+}$cells can be induced during inflammatory conditions (Chang et al., 2011; Hardman et al., 2013; Tjota et al., 2013), it does not appear to be expressed by infiltrating immune cells in the CNS in this model with no CD45 co-localisation (data not shown). Thus while these infiltrating immune cells do not produce IL-33, many of them express the receptor and therefore likely respond to IL-33 released in the CNS under inflammatory conditions. The reduction in availability of IL-33responsive cells in anti-CD52 treated mice may potentially contribute to the reduced CNS pathogenesis as the IL-33/ST2 axis has been shown to have important roles in various CNS 
diseases through activating infiltrating immune and local CNS cells (Fu et al., 2016; Yasuoka et al., 2011; Zarpelon et al., 2016).

In summary, murine anti-CD52 replicates the protective effect of alemtuzumab in RRMS through mechanisms of depleting lymphocytes and inhibiting splenocyte cytokine production. The inhibitory effect of anti-CD52 antibody on neuroinflammation is associated with altered expression levels of IL-33 and ST2 both in peripheral tissues and within the CNS, indicating IL-33/ST2 pathway may be involved in the mechanisms of action of anti-CD52 in EAE.

\section{Conflict of Interest}

This study was supported by a grant from Genzyme Corporation, a Sanofi company. 


\section{References:}

Allan, D., Fairlie-Clarke, K.J., Elliott, C., Schuh, C., Barnett, S.C., Lassmann, H., Linnington, C., Jiang, H.-R., 2016. Role of IL-33 and ST2 signalling pathway in multiple sclerosis: expression by oligodendrocytes and inhibition of myelination in central nervous system. Acta Neuropathol. Commun. 4, 75. doi:10.1186/s40478-016-0344-1

Baekkevold, E.S., Roussigné, M., Yamanaka, T., Johansen, F.-E., Jahnsen, F.L., Amalric, F., Brandtzaeg, P., Erard, M., Haraldsen, G., Girard, J.-P., 2003. Molecular characterization of NFHEV, a nuclear factor preferentially expressed in human high endothelial venules. Am. J. Pathol. 163, 69-79. doi:10.1016/S0002-9440(10)63631-0

Bartemes, K.R., Iijima, K., Kobayashi, T., Kephart, G.M., McKenzie, A.N., Kita, H., 2012. IL-33Responsive Lineage-CD25+CD44hi Lymphoid Cells Mediate Innate Type 2 Immunity and Allergic Inflammation in the Lungs. J. Immunol. 188, 1503-13. doi:10.4049/jimmunol.1102832

Bonilla, W. V., Frohlich, A., Senn, K., Kallert, S., Fernandez, M., Johnson, S., Kreutzfeldt, M., Hegazy, A.N., Schrick, C., Fallon, P.G., Klemenz, R., Nakae, S., Adler, H., Merkler, D., Lohning, M., Pinschewer, D.D., 2012. The Alarmin Interleukin-33 Drives Protective Antiviral CD8+ T Cell Responses. Science (80-. ). 335, 984-989. doi:10.1126/science.1215418

Chang, Y.-J., Kim, H.Y., Albacker, L. a., Baumgarth, N., McKenzie, A.N.J., Smith, D.E., Dekruyff, R.H., Umetsu, D.T., 2011. Innate lymphoid cells mediate influenza-induced airway hyperreactivity independently of adaptive immunity. Nat. Immunol. 12, 631-38. doi:10.1038/ni.2045

Chapuis, J., Hot, D., Hansmannel, F., Kerdraon, O., Ferreira, S., Hubans, C., Maurage, C.A., Huot, L., Bensemain, F., Laumet, G., Ayral, A.M., Fievet, N., Hauw, J.J., DeKosky, S.T., Lemoine, Y., Iwatsubo, T., Wavrant-Devrièze, F., Dartigues, J.F., Tzourio, C., Buée, L., Pasquier, F., Berr, C., Mann, D., Lendon, C., Alpérovitch, A., Kamboh, M.I., Amouyel, P., Lambert, J.C., 2009. Transcriptomic and genetic studies identify IL-33 as a candidate gene for Alzheimer's disease. Mol. Psychiatry 14, 1004-16. doi:10.1038/mp.2009.10

Chen, H., Sun, Y., Lai, L., Wu, H., Xiao, Y., Ming, B., Gao, M., Zou, H., Xiong, P., Xu, Y., Tan, Z., Gong, F., Zheng, F., 2015. Interleukin-33 is released in spinal cord and suppresses experimental autoimmune encephalomyelitis in mice. Neuroscience 308, 157-68. doi:10.1016/j.neuroscience.2015.09.019

Christophi, G.P., Gruber, R.C., Panos, M., Christophi, R.L., Jubelt, B., Massa, P.T., 2012. Interleukin33 upregulation in peripheral leukocytes and CNS of multiple sclerosis patients. Clin. Immunol. 142, 308-19. doi:10.1016/j.clim.2011.11.007.Interleukin-33

Cohen, J.A., Coles, A.J., Arnold, D.L., Confavreux, C., Fox, E.J., Hartung, H.P., Havrdova, E., Selmaj, K.W., Weiner, H.L., Fisher, E., Brinar, V. V., Giovannoni, G., Stojanovic, M., Ertik, B.I., Lake, S.L., Margolin, D.H., Panzara, M.A., Compston, D.A.S., 2012. Alemtuzumab versus interferon beta 1a as first-line treatment for patients with relapsing-remitting multiple sclerosis: A randomised controlled phase 3 trial. Lancet 380, 1819-28. doi:10.1016/S01406736(12)61769-3

Coles, A.J., Twyman, C.L., Arnold, D.L., Cohen, J.A., Confavreux, C., Fox, E.J., Hartung, H.P., Havrdova, E., Selmaj, K.W., Weiner, H.L., Miller, T., Fisher, E., Sandbrink, R., Lake, S.L., 
Margolin, D.H., Oyuela, P., Panzara, M.A., Compston, D.A.S., 2012. Alemtuzumab for patients with relapsing multiple sclerosis after disease-modifying therapy: A randomised controlled phase 3 trial. Lancet 380, 1829-39. doi:10.1016/S0140-6736(12)61768-1

Compston, A., Coles, A., 2008. Multiple sclerosis. Lancet 372, 1502-17. doi:10.1016/S01406736(08)61620-7

Cox, A.L., Thompson, S.A.J., Jones, J.L., Robertson, V.H., Hale, G., Waldmann, H., Compston, D.A.S., Coles, A.J., 2005. Lymphocyte homeostasis following therapeutic lymphocyte depletion in multiple sclerosis. Eur. J. Immunol. 35, 3332-42. doi:10.1002/eji.200535075

Dieplinger, B., Mueller, T., 2015. Soluble ST2 in heart failure. Clin. Chim. Acta 443, 57-70. doi:10.1016/j.cca.2014.09.021

Fineberg, N.A., Haddad, P.M., Carpenter, L., Gannon, B., Sharpe, R., Young, A.H., Joyce, E., Rowe, J., Wellsted, D., Nutt, D.J., Sahakian, B.J., 2013. The size, burden and cost of disorders of the brain in the UK. J. Psychopharmacol. 27, 761-70. doi:10.1177/0269881113495118

Franca, R.F.O., Costa, R.S., Silva, J.R., Peres, R.S., Mendonça, L.R., Colón, D.F., Alves-Filho, J.C., Cunha, F.Q., 2016. IL-33 signaling is essential to attenuate viral-induced encephalitis development by downregulating iNOS expression in the central nervous system. J. Neuroinflammation 13, 159. doi:10.1186/s12974-016-0628-1

Fu, A.K.Y., Hung, K.-W., Yuen, M.Y.F., Zhou, X., Mak, D.S.Y., Chan, I.C.W., Cheung, T.H., Zhang, B., Fu, W.-Y., Liew, F.Y., Ip, N.Y., 2016. IL-33 ameliorates Alzheimer's disease-like pathology and cognitive decline. Proc. Natl. Acad. Sci. 113, 2705-13. doi:10.1073/pnas.1604032113

Gadani, S.P., Walsh, J.T., Smirnov, I., Zheng, J., Kipnis, J., 2015. The Glia-Derived Alarmin IL-33 Orchestrates the Immune Response and Promotes Recovery following CNS Injury. Neuron 85, 703-9. doi:10.1016/j.neuron.2015.01.013

Gross, C.C., Ahmetspahic, D., Ruck, T., Schulte-Mecklenbeck, A., Schwarte, K., Jörgens, S., Scheu, S., Windhagen, S., Graefe, B., Melzer, N., Klotz, L., Arolt, V., Wiendl, H., Meuth, S.G., Alferink, J., 2016. Alemtuzumab treatment alters circulating innate immune cells in multiple $\begin{array}{lllll}\text { sclerosis. } \quad \text { Neurol. } \quad-\quad \text { Neuroimmunol. Neuroinflammation } 3, & \text { e289. }\end{array}$ doi:10.1212/NXI.0000000000000289

Guarnera, C., Bramanti, P., Mazzon, E., 2017. Alemtuzumab: A review of efficacy and risks in the treatment of relapsing remitting multiple sclerosis. Ther. Clin. Risk Manag. 13, 871-879. doi:10.2147/TCRM.S134398

Hardman, C.S., Panova, V., Mckenzie, A.N.J., 2013. IL-33 citrine reporter mice reveal the temporal and spatial expression of IL-33 during allergic lung inflammation. Eur. J. Immunol. 43, 488-98. doi:10.1002/eji.201242863

Havrdova, E., Arnold, D.L., Cohen, J.A., Hartung, H.P., Fox, E.J., Giovannoni, G., Schippling, S., Selmaj, K.W., Traboulsee, A., Compston, D.A.S., Margolin, D.H., Thangavelu, K., Rodriguez, C.E., Jody, D., Hogan, R.J., Xenopoulos, P., Panzara, M.A., Coles, A.J., 2017. Alemtuzumab CARE-MS i 5-year follow-up: Durable efficacy in the absence of continuous MS therapy. Neurology 89, 1107-1116. doi:10.1212/WNL.0000000000004313 
Hayakawa, H., Hayakawa, M., Kume, A., Tominaga, S.I., 2007. Soluble ST2 blocks interleukin-33 signaling in allergic airway inflammation. J. Biol. Chem. 282, 26369-26380. doi:10.1074/jbc.M704916200

Hotta, R., Ohira, M., Matsuura, T., Muraoka, I., Tryphonopoulos, P., Fan, J., Tekin, A., Selvaggi, G., Levi, D., Ruiz, P., Ricordi, C., Vianna, R., Ohdan, H., Waldmann, H., Tzakis, A.G., Nishida, S., 2016. CD52-negative NK cells are abundant in the liver and less susceptible to alemtuzumab treatment. PLoS One 11, 1-13. doi:10.1371/journal.pone.0161618

Hung, L.-Y., Lewkowich, I.P., Dawson, L.A., Downey, J., Yang, Y., Smith, D.E., Herbert, D.R., 2013. IL-33 drives biphasic IL-13 production for noncanonical Type 2 immunity against hookworms. Proc. Natl. Acad. Sci. U. S. A. 110, 282-87. doi:10.1073/pnas.1206587110

Jiang, H.-R., Milovanović, M., Allan, D., Niedbala, W., Besnard, A.-G., Fukada, S.Y., Alves-Filho, J.C., Togbe, D., Goodyear, C.S., Linington, C., Xu, D., Lukic, M.L., Liew, F.Y., 2012. IL-33 attenuates EAE by suppressing IL-17 and IFN- $\gamma$ production and inducing alternatively activated macrophages. Eur. J. Immunol. 42, 1804-14. doi:10.1002/eji.201141947

Lohning, M., Stroehmann, A., Coyle, A.J., Grogan, J.L., Lin, S., Gutierrez-Ramos, J.-C., Levinson, D., Radbruch, A., Kamradt, T., 1998. T1/ST2 is preferentially expressed on murine Th2 cells, independent of interleukin 4, interleukin 5, and interleukin 10, and important for Th2 effector function. Immunology 95, 6930-6935. doi:10.1073/pnas.95.12.6930

Louten, J., Rankin, A.L., Li, Y., Murphy, E.E., Beaumont, M., Moon, C., Bourne, P., McClanahan, T.K., Pflanz, S., de Waal Malefyt, R., 2011. Endogenous IL-33 enhances Th2 cytokine production and T-cell responses during allergic airway inflammation. Int. Immunol. 23, 307-15. doi:10.1093/intimm/dxr006

Mackenzie, I.S., Morant, S. V, Bloomfield, G. a, MacDonald, T.M., O’Riordan, J., 2014. Incidence and prevalence of multiple sclerosis in the UK 1990-2010: a descriptive study in the General Practice Research Database. J. Neurol. Neurosurg. Psychiatry 85, 76-84. doi:10.1136/jnnp2013-305450

Miller, A.M., Xu, D., Asquith, D.L., Denby, L., Li, Y., Sattar, N., Baker, A.H., McInnes, I.B., Liew, F.Y., 2008. IL-33 reduces the development of atherosclerosis. J. Exp. Med. 205, 339-46. doi:10.1084/jem.20071868

Milovanovic, M., Volarevic, V., Ljujic, B., Radosavljevic, G., Jovanovic, I., Arsenijevic, N., Lukic, M.L., 2012. Deletion of IL-33R (ST2) Abrogates Resistance to EAE in BALB/C Mice by Enhancing Polarization of APC to Inflammatory Phenotype. PLoS One 7, 1-13. doi:10.1371/journal.pone.0045225

Monticelli, L.A., Sonnenberg, G.F., Abt, M.C., Alenghat, T., Ziegler, C.G., Doering, T.A., Angelosanto, J.M., Laidlaw, B.J., Yang, C.Y., Sathaliyawala, T., Kubota, M., Turner, D., Diamond, J.M., Goldrath, A.W., Farber, D.L., Collman, R.G., Wherry, E.J., Artis, D., 2011. Innate lymphoid cells promote lung-tissue homeostasis after infection with influenza virus. Nat. Immunol. 12, 1045-54. doi:10.1031/ni.2131

Moritz, D.R., Rodewald, H.R., Gheyselinck, J., Klemenz, R., 1998. The IL-1 receptor-related T1 antigen is expressed on immature and mature mast cells and on fetal blood mast cell progenitors. 
J. Immunol. 161, 4866-4874.

Moro, K., Yamada, T., Tanabe, M., Takeuchi, T., Ikawa, T., Kawamoto, H., Furusawa, J.-I., Ohtani, M., Fujii, H., Koyasu, S., 2010. Innate production of T(H)2 cytokines by adipose tissueassociated c-Kit(+)Sca-1(+) lymphoid cells. Nature 463, 540-44. doi:10.1038/nature08636

Neill, D.R., Wong, S.H., Bellosi, A., Flynn, R.J., Daly, M., Langford, T.K. a, Bucks, C., Kane, C.M., Fallon, P.G., Pannell, R., Jolin, H.E., McKenzie, A.N.J., 2010. Nuocytes represent a new innate effector leukocyte that mediates type-2 immunity. Nature 464, 1367-1370. doi:10.1038/nature08900

Oboki, K., Ohno, T., Kajiwara, N., Arae, K., Morita, H., Ishii, A., Nambu, A., Abe, T., Kiyonari, H., Matsumoto, K., Sudo, K., Okumura, K., Saito, H., Nakae, S., 2010. IL-33 is a crucial amplifier of innate rather than acquired immunity. Proc Natl Acad Sci U S A 107, 18581-86. doi:1003059107 [pii]\r10.1073/pnas.1003059107

Pant, A.B., Wang, Y., Mielcarz, D.W., Kasper, E.J., Telesford, K.M., Mishra, M., Haque, A., Smith, J., Kasper, L.H., Begum-Haque, S., 2016. Alteration of CD39+Foxp3+ CD4 T cell and cytokine levels in EAE/MS following anti-CD52 treatment. J. Neuroimmunol. 303, 22-30. doi:10.1016/j.jneuroim.2016.12.010

Price, A.E., Liang, H.-E., Sullivan, B.M., Reinhardt, R.L., Eisley, C.J., Erle, D.J., Locksley, R.M., 2010. Systemically dispersed innate IL-13-expressing cells in type 2 immunity. Proc. Natl. Acad. Sci. 107, 11489-11494. doi:10.1073/pnas.1003988107

Pugliatti, M., Sotgiu, S., Rosati, G., 2002. The worldwide prevalence of multiple sclerosis. Clin. Neurol. Neurosurg. 104, 182-91.

Rao, S.P., Sancho, J., Campos-Rivera, J., Boutin, P.M., Severy, P.B., Weeden, T., Shankara, S., Roberts, B.L., Kaplan, J.M., 2012. Human peripheral blood mononuclear cells exhibit heterogeneous CD52 expression levels and show differential sensitivity to alemtuzumab mediated cytolysis. PLoS One 7, 1-12. doi:10.1371/journal.pone.0039416

Sanada, S., Hakuno, D., Higgins, L.J., Schreiter, E.R., McKenzie, A.N.J., Lee, R.T., 2007. IL-33 and ST2 comprise a critical biomechanically induced and cardioprotective signaling system. J. Clin. Invest. 117, 1538-49. doi:10.1172/JCI30634

Schiering, C., Krausgruber, T., Chomka, A., Fröhlich, A., Adelmann, K., Wohlfert, E. a, Pott, J., Griseri, T., Bollrath, J., Hegazy, A.N., Harrison, O.J., Owens, B.M.J., Löhning, M., Belkaid, Y., Fallon, P.G., Powrie, F., 2014. The alarmin IL-33 promotes regulatory T-cell function in the intestine. Nature 513, 564-8. doi:10.1038/nature13577

Schmitz, J., Owyang, A., Oldham, E., Song, Y., Murphy, E., McClanahan, T.K., Zurawski, G., Moshrefi, M., Qin, J., Li, X., Gorman, D.M., Bazan, J.F., Kastelein, R.A., 2005. IL-33, an interleukin-1-like cytokine that signals via the IL-1 receptor-related protein ST2 and induces T helper type 2-associated cytokines. Immunity 23, 479-90. doi:10.1016/j.immuni.2005.09.015

Smithgall, M.D., Comeau, M.R., Park Yoon, B.R., Kaufman, D., Armitage, R., Smith, D.E., 2008. IL33 amplifies both Th1- and Th2-type responses through its activity on human basophils, allergen-reactive Th 2 cells, iNKT and NK Cells. Int. Immunol. 20, 1019-1030. doi:10.1093/intimm/dxn060 
Thompson, S.A.J., Jones, J.L., Cox, A.L., Compston, D.A.S., Coles, A.J., 2010. B-Cell reconstitution and BAFF after alemtuzumab (Campath-1H) treatment of multiple sclerosis. J. Clin. Immunol. 30, 99-105. doi:10.1007/s10875-009-9327-3

Tjota, M.Y., Williams, J.W., Lu, T., Clay, B.S., Byrd, T., Hrusch, C.L., Decker, D.C., Araujo, C.A. De, Bryce, P.J., Sperling, A.I., 2013. IL-33 - dependent induction of allergic lung inflammation by Fc $\gamma$ RIII signaling. J. Clin. Investig. 123, 2287-97. doi:10.1172/JCI63802DS1

Turner, M.J., Pang, P.T., Chretien, N., Havari, E., LaMorte, M.J., Oliver, J., Pande, N., Masterjohn, E., Carter, K., Reczek, D., Brondyk, W., Roberts, B.L., Kaplan, J.M., Siders, W.M., 2015. Reduction of inflammation and preservation of neurological function by anti-CD52 therapy in murine experimental autoimmune encephalomyelitis. J. Neuroimmunol. 285, 4-12. doi:10.1016/j.jneuroim.2015.05.018

von Kutzleben, S., Pryce, G., Giovannoni, G., Baker, D., 2016. Depletion of CD52 positive cells inhibits the development of CNS autoimmune disease, but deletes an immune-tolerance promoting CD8 T cell population. Implications for secondary autoimmunity of alemtuzumab in multiple sclerosis. Immunology 44, 444-55. doi:10.1111/imm.12696

Weiner, H.L., 2008. A shift from adaptive to innate immunity: a potential mechanism of disease progression in multiple sclerosis. J. Neurol. 255 Suppl, 3-11. doi:10.1007/s00415-008-1002-8

Xiangyang, Z., Lutian, Y., Lin, Z., Liping, X., Hui, S., Jing, L., 2012. Increased levels of interleukin33 associated with bone erosion and interstitial lung diseases in patients with rheumatoid arthritis. Cytokine 58, 6-9. doi:10.1016/j.cyto.2011.12.010

Xu, D., Chan, W.L., Leung, B.P., Huang, F. p, Wheeler, R., Piedrafita, D., Robinson, J.H., Liew, F.Y., 1998. Selective expression of a stable cell surface molecule on type 2 but not type 1 helper T cells. J. Exp. Med. 187, 787-94.

Xu, D., Jiang, H.-R., Kewin, P., Li, Y., Mu, R., Fraser, A.R., Pitman, N., Kurowska-Stolarska, M., McKenzie, A.N.J., McInnes, I.B., Liew, F.Y., 2008. IL-33 exacerbates antigen-induced arthritis by activating mast cells. Proc. Natl. Acad. Sci. U. S. A. 105, 10913-10918. doi:10.1073/pnas.0801898105

Yang, Q., Li, G., Zhu, Y., Liu, L., Chen, E., Turnquist, H., Zhang, X., Finn, O.J., Chen, X., Lu, B., 2011. IL-33 synergizes with TCR and IL-12 signaling to promote the effector function of CD8 + T cells. Eur. J. Immunol. 41, 3351-3360. doi:10.1002/eji.201141629

Yasuda, K., Muto, T., Kawagoe, T., Matsumoto, M., Sasaki, Y., Matsushita, K., Taki, Y., FutatsugiYumikura, S., Tsutsui, H., Ishii, K.J., Yoshimoto, T., Akira, S., Nakanishi, K., 2012. Contribution of IL-33-activated type II innate lymphoid cells to pulmonary eosinophilia in intestinal nematode-infected mice. Proc. Natl. Acad. Sci. U. S. A. 109, 3451-56. doi:10.1073/pnas.1201042109

Yasuoka, S., Kawanokuchi, J., Parajuli, B., Jin, S., Doi, Y., Noda, M., Sonobe, Y., Takeuchi, H., Mizuno, T., Suzumura, A., 2011. Production and functions of IL-33 in the central nervous system. Brain Res. 1385, 8-17. doi:10.1016/j.brainres.2011.02.045

Zarpelon, A.C., Rodrigues, F.C., Lopes, A.H., Souza, G.R., Carvalho, T.T., Pinto, L.G., Xu, D., Ferreira, S.H., Alves-Filho, J.C., McInnes, I.B., Ryffel, B., Quesniaux, V.F.J., Reverchon, F., 
Mortaud, S., Menuet, A., Liew, F.Y., Cunha, F.Q., Cunha, T.M., Verri, W.A., 2016. Spinal cord oligodendrocyte-derived alarmin IL-33 mediates neuropathic pain. FASEB J. 30, 54-65. doi:10.1096/fj.14-267146

Zhang, F., Tossberg, J.T., Spurlock, C.F., Yao, S.-Y., Aune, T.M., Sriram, S., 2014. Expression of IL33 and its epigenetic regulation in Multiple Sclerosis. Ann. Clin. Transl. Neurol. 1, 307-18. doi:10.1002/acn3.47

Zhang, X., Tao, Y., Chopra, M., Ahn, M., Marcus, K.L., Choudhary, N., Zhu, H., Markovic-Plese, S., 2013. Differential Reconstitution of T Cell Subsets following Immunodepleting Treatment with Alemtuzumab (Anti-CD52 Monoclonal Antibody) in Patients with Relapsing-Remitting Multiple Sclerosis. J. Immunol. 191, 5867-74. doi:10.4049/jimmunol.1301926 


\section{Figure Legends}

Figure 1. Anti-CD52 treatment ameliorates EAE severity and reduces CNS inflammation. (A) Mice were immunised with $\mathrm{MOG}_{35-55}$ peptide and following onset of clinical signs of disease, treated with either vehicle (PBS) or $10 \mathrm{mg} / \mathrm{kg}$ murine anti-CD52 from days 13 to 17 , denoted by bar on $\mathrm{X}$ axis. $\mathrm{n}=22$ day $0-13, \mathrm{n}=18$ day $13-19, \mathrm{n}=10$ day 2028. Two way ANOVA with repeated measures and Bonferroni post-test. ${ }^{*} \mathrm{P}<0.05$, ${ }^{* *} \mathrm{p}<0.01$, $* * * \mathrm{p}<0.001$. (B) Spinal cords were harvested following the final dose of anti-CD52, day 18, and H\&E staining carried out as well as immunohistochemical staining of the cell surface markers CD45, CD4 and F4/80. Representative images are shown. (C) Quantification of CD45, CD4 and F4/80 positive staining in vehicle $(n=8)$ and anti-CD52 $(n=9)$ treated mice. Unpaired two-tailed students t test. ${ }^{* * *} \mathrm{p}<0.001$.

Figure 2. Circulating and splenic lymphocytes are depleted in EAE mice following antiCD52 treatment in EAE mice: Single cell suspensions were obtained from (A) blood and (B) spleens of anti-CD52 or vehicle treated mice at day $18(n=9)$ or day $28(n=10)$. Cells were stained for the cell surface markers CD4, CD8, CD19 and B220 and analysed by flow cytometry. Representative flow cytometry plots from EAE day 18 mice are shown. Unpaired two-tailed students t test. ${ }^{*} \mathrm{p}<0.05,{ }^{* *} \mathrm{p}<0.01,{ }^{* * *} \mathrm{p}<0.001$.

Figure 3. Anti-CD52 depletes circulating NK cells but not other innate immune cells in EAE mice. Single cell suspensions were obtained from (A) blood and (B) spleens of antiCD52 or vehicle treated EAE mice at day $18(n=4)$ or day $28(n=5)$ after immunisation. Cells were stained for the cell surface markers CD49b, CD11b and CD11c and analysed by flow cytometry. Unpaired two-tailed students t test. ${ }^{* *} \mathrm{p}<0.01$. 
Figure 4. Anti-CD52 treatment reduces systemic cytokine production in EAE mice. (A) Blood samples were harvested from vehicle or anti-CD52 treated EAE mice at day $10(n=6)$, day $18(n=10)$ or day $28(n=5)$ and cytokine levels determined by ELISA. Unpaired twotailed students t test. ${ }^{*} \mathrm{p}<0.05$. (B) Spleens were harvested at day $10(\mathrm{n}=6)$, day $18(\mathrm{n}=8)$ or day $28(\mathrm{n}=8)$ after immunisation and individual cell suspensions obtained. Cells were stimulated with $\mathrm{MOG}_{35-55}$ for 72 hours and supernatants collected for analysis of cytokine production by ELISA. Unpaired two-tailed students t test. ${ }^{* *} \mathrm{p}<0.01,{ }^{* * *} \mathrm{p}<0.001$.

Figure 5. Anti-CD52 treatment alters the expression of both IL-33 and ST2 in the CNS of EAE mice. (A) Spinal cords were harvested from vehicle or anti-CD52 treated mice at day $10(n=6)$, day $18(n=10)$ or day $28(n=5)$ and homogenised and IL-33 and sST2 levels determined by ELISA. Unpaired two-tailed students $\mathrm{t}$ test. $* * * \mathrm{p}<0.001$. (B) Immunohistochemical staining of IL-33 and ST2 in spinal cord sections, representative images of day 18 spinal cords are shown. (C) Quantification of IL- $33^{+}$or ST2 ${ }^{+}$cells in the spinal cords of vehicle $(n=8)$ and anti-CD52 $(n=9)$ treated EAE mice. Unpaired two-tailed students t test. ${ }^{* *} \mathrm{p}<0.01$.

Figure 6. Anti-CD52 treatment reduces the number of ST2-expressing astrocytes, oligodendrocytes and infiltrating immune cells present in the spinal cord of EAE mice. Spinal cords were harvested on day 18 from vehicle or anti-CD52 treated mice following the final dose of anti-CD52 and double immunofluorescent staining of ST2 and (A) GFAP (n=5), (B) $\mathrm{O} 1(\mathrm{n}=5)$ and (C) CD45 (n=5) was performed. Representative images shown. Scale bars $=50 \mu \mathrm{M}$. Quantification of the number of (D) single positive or (E) double positive cells was achieved using ImageJ. Unpaired two-tailed students t test. ${ }^{*} \mathrm{p}<0.05{ }^{* * *} \mathrm{p}<0.001$. 
Figure 1
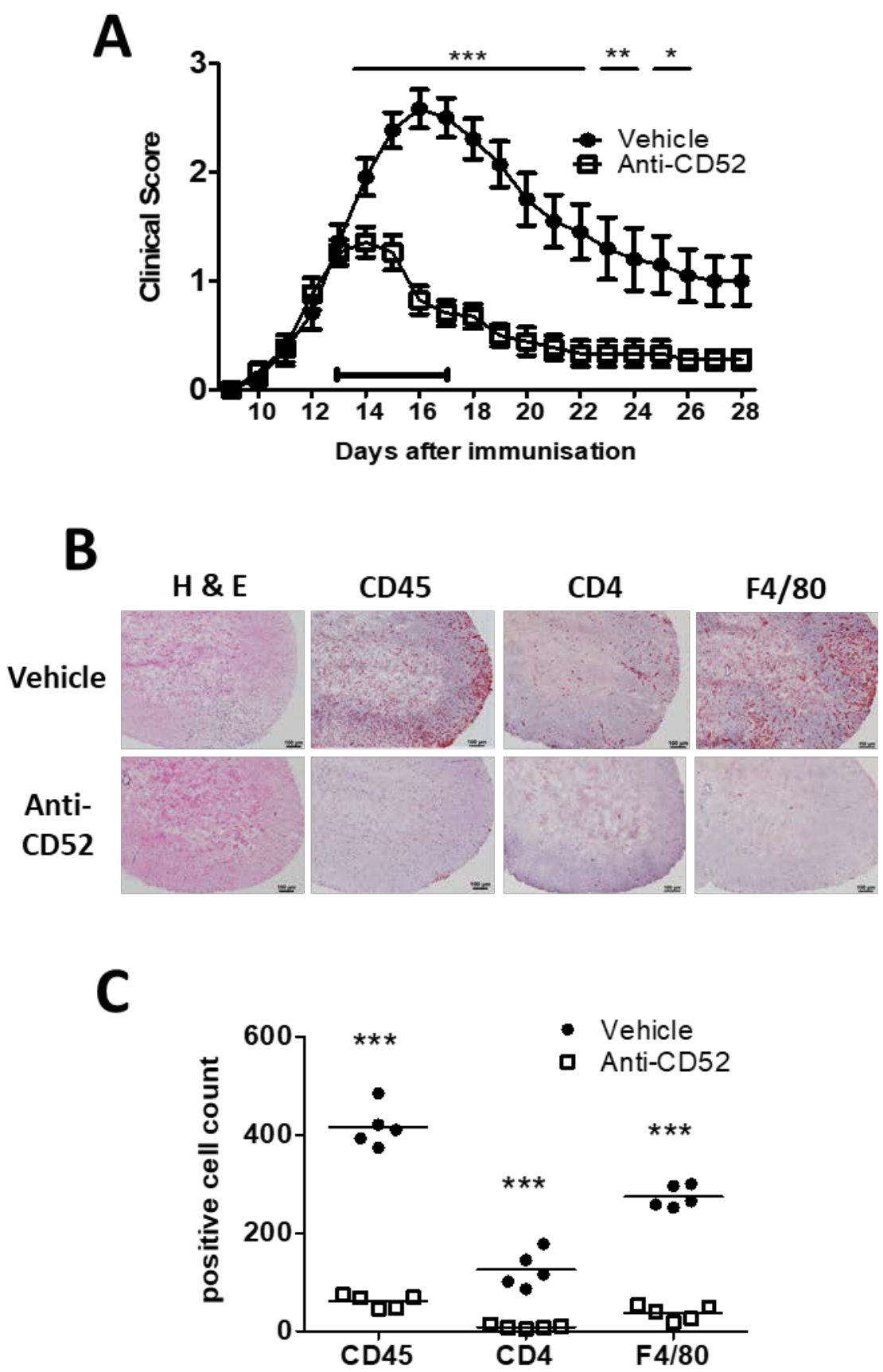
Figure 2

\section{A Blood}
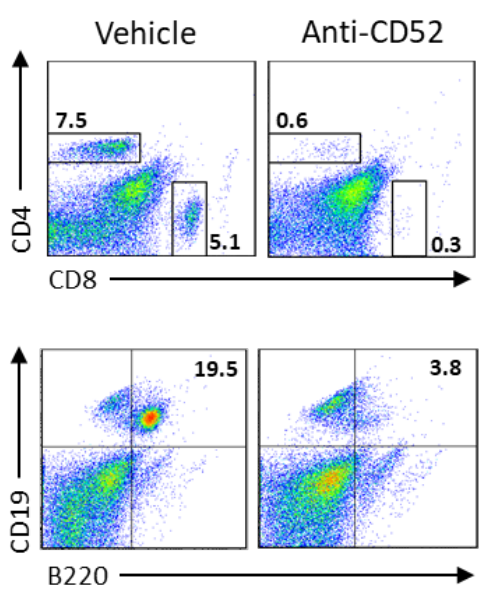

\section{B Spleen}
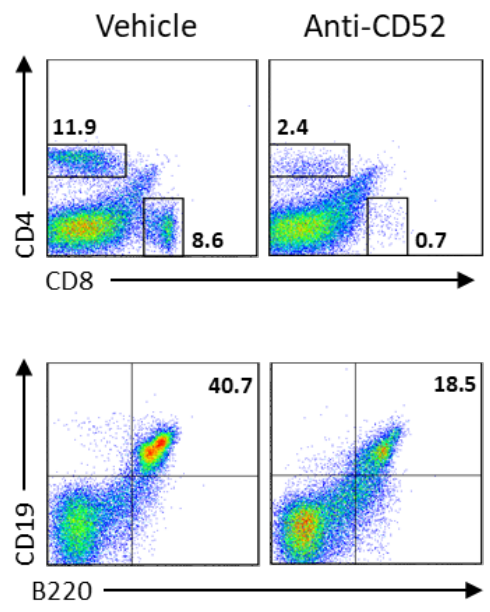

$\mathrm{CD}^{+}{ }^{+}$
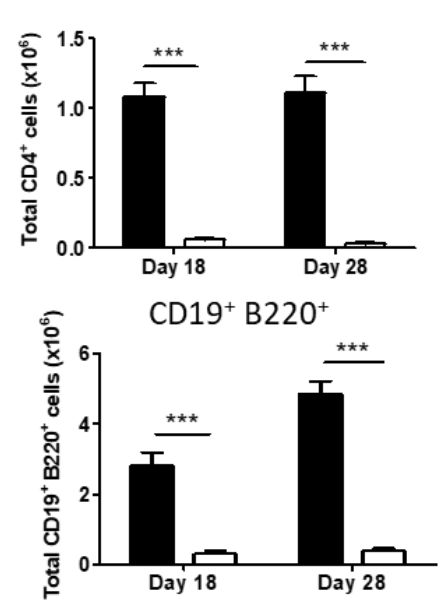

$\mathrm{CD}^{+}$

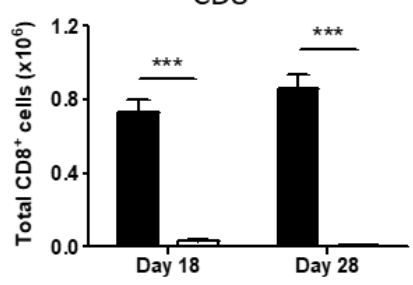

Vehicle

$\square$ Anti-CD52

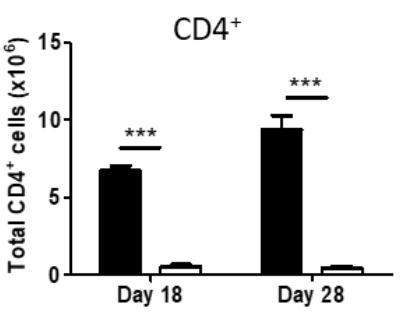

CD19+ B220

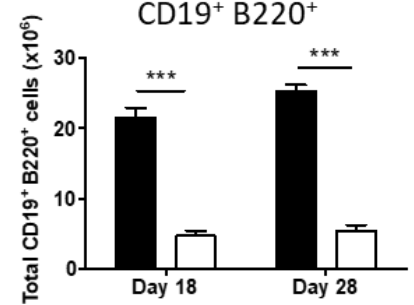

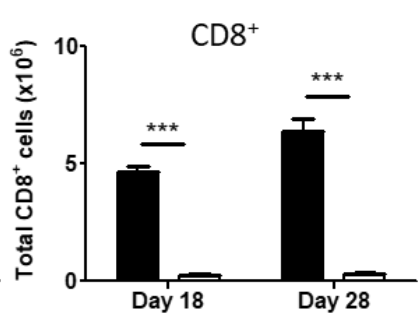

Vehicle $\square$ Anti-CD52 
Figure 3

A Blood

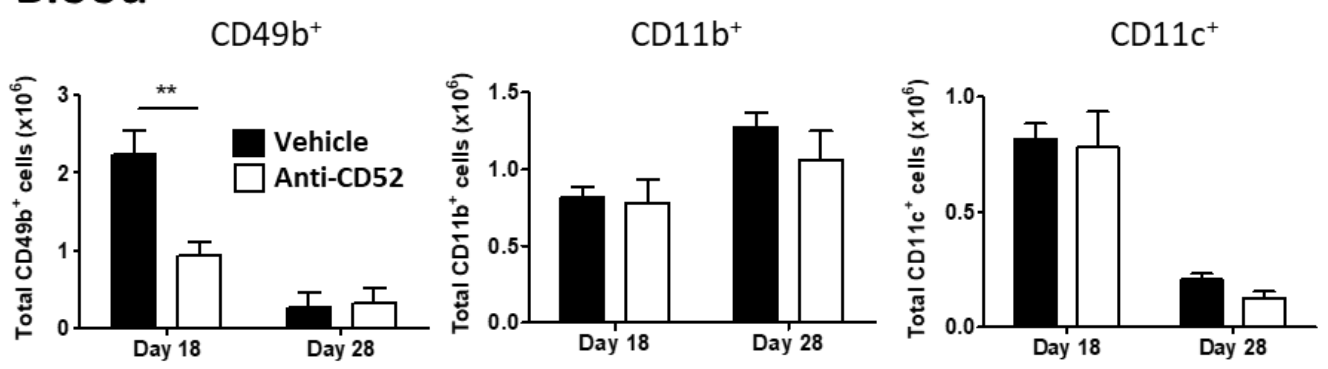

B Spleen
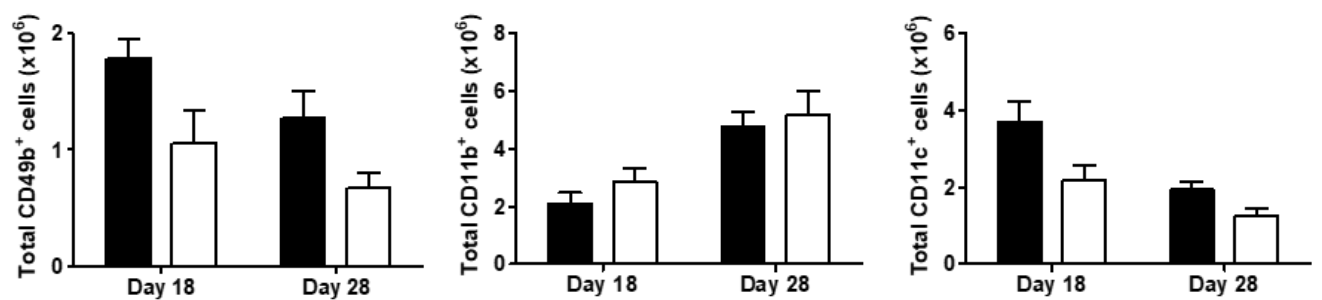
Figure 4

A

IL-6

IL-33

sST2
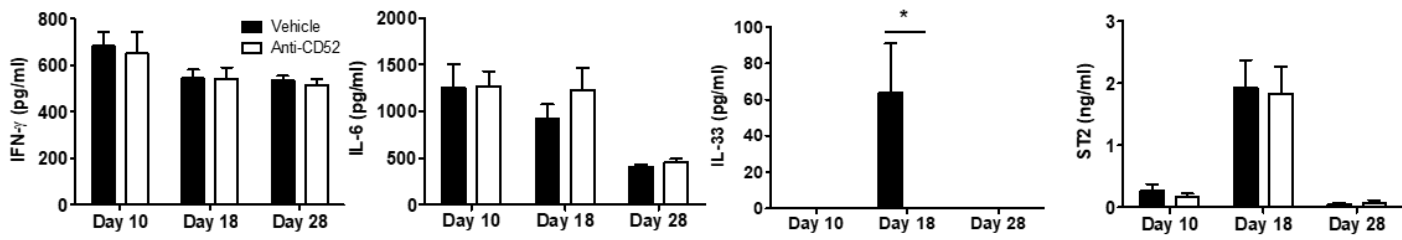

B

IL-17

IFN- $\boldsymbol{\gamma}$

IL-6

IL-10
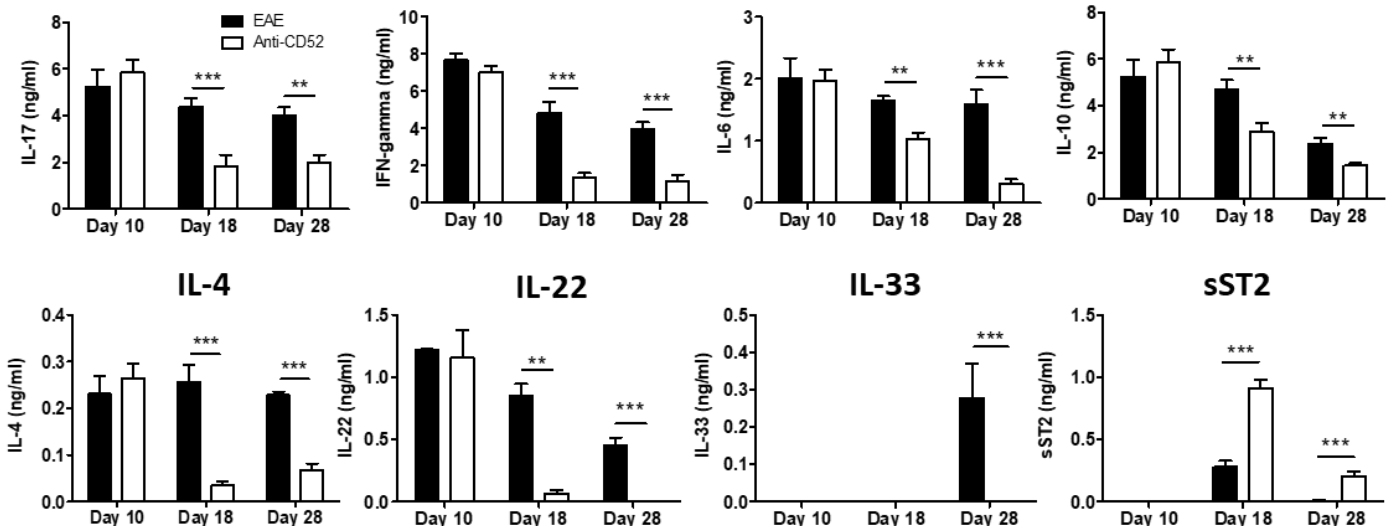

IL-22

IL-33

sST2
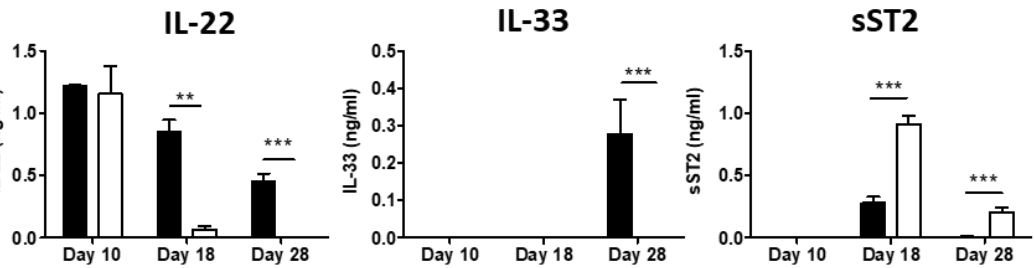


\section{Figure 5}

A IL-33

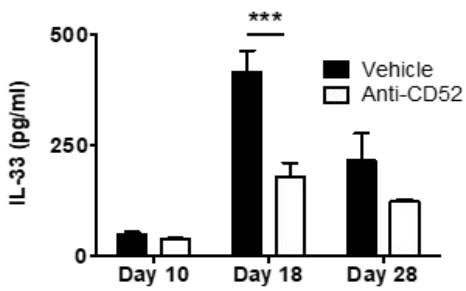

B

Vehicle

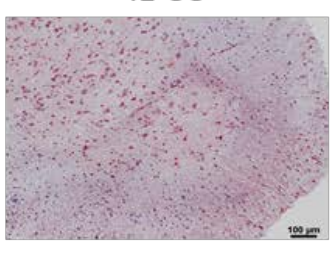

Anti-

CD52

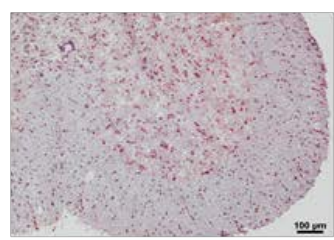

C

IL-33

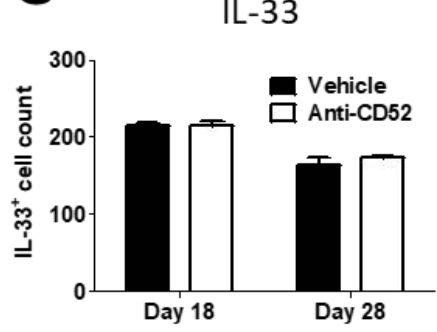

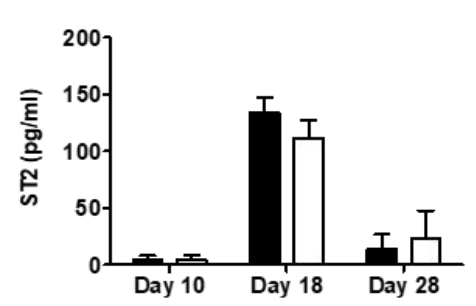

sST2

ST2
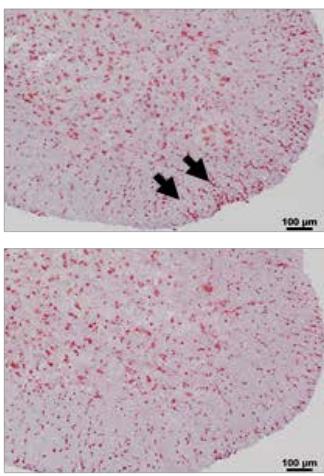

ST2

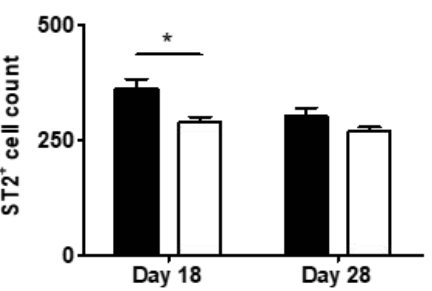




\section{Figure 6}
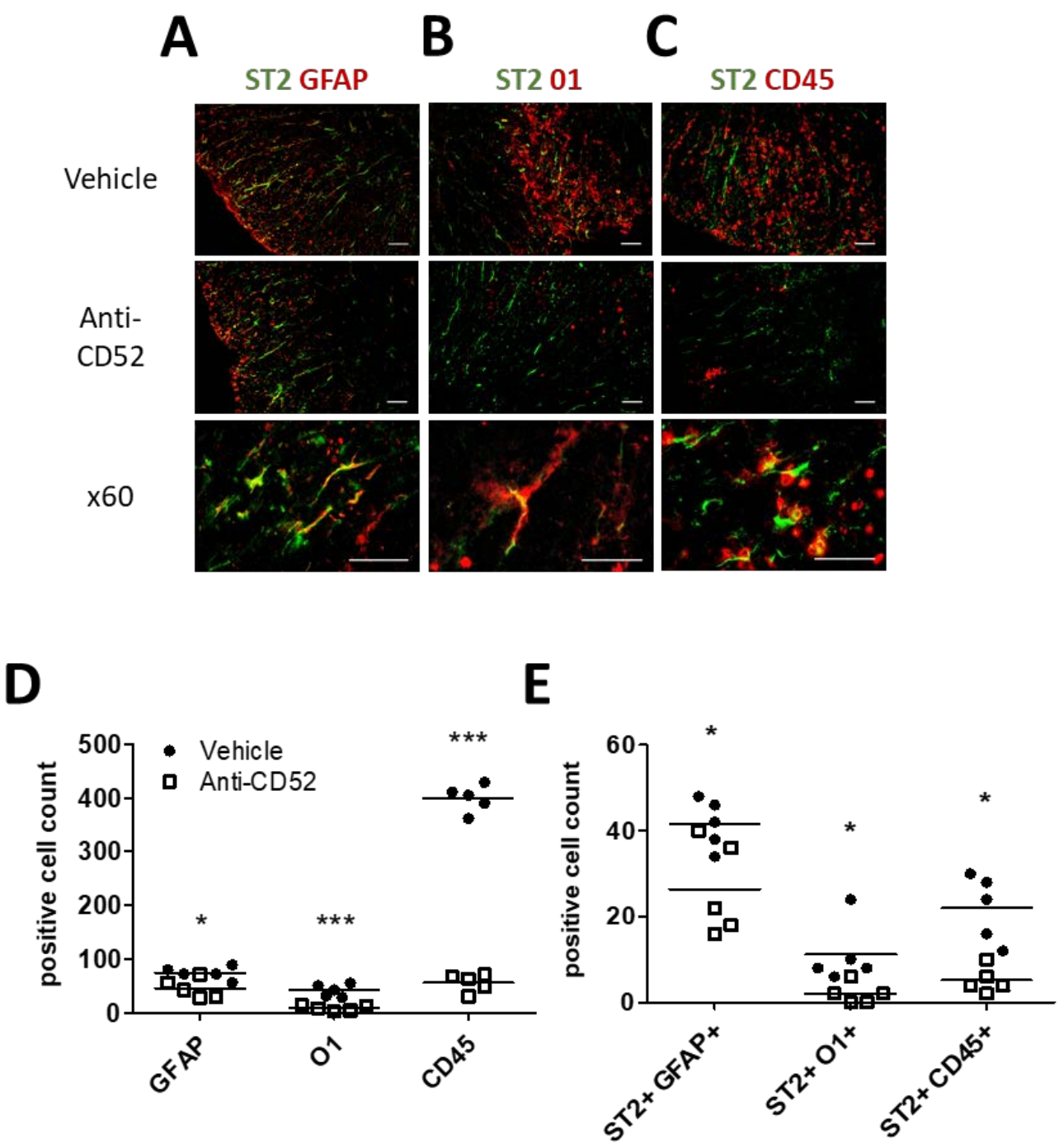

Figure 6 